\title{
ECONOMIC AND ECOLOGICAL ADVANTAGES OF INNOVATIVE PROJECT IMPLEMENTATION AT WOODWORKING INDUSTRY
}

Introduction. Using the innovative development principles is a strategic trend of developed countries, whose industrial production is clearly technology-and-science intensive oriented. This applies primarily to the national energy producing sector, requiring search for innovative development strategies.

This search direction is determined by specific reasons, the essential ones being following:

- Objective exhaustion of energy sources reserves;

The need for effectively implemented various kinds of energy saving programs;

- Instability of production of various carbohydrates due to economic, political and technological circumstances;

- Reduction of energy resources, that causes to initiate the development of innovative capitalintensive projects which tend to become one of the ways to solve energy supply problems;

- Complications in transport and storage of hydrocarbons as well as their processing products;

- Actual revealing of a new stage in the world energy industry development and increased efficient competition from alternative sources of energy side.

Under current level and rate of scientific technical progress, the power consumption can be achieved mainly through the use of fossil fuel energy sources that are non-reproducible. But the developed countries show a steady dynamics of energy consumption from renewable energy sources, the most attractive source thereof being the wood.

Therefore, high priority is tribute to the coverage of issues for innovative projects implementation at woodworking industry enterprises, such projects, firstly, are aimed to make effective use of raw materials waste, and, secondly, to the manufacturing of competitive products. This topic importance is seconded with that the introduction of innovative energy-saving projects at the woodworking industry enterprises is initially approbation-oriented and, when successful, will be followed by wide-spread introduction in other sectors of the national economy, especially in the energy industry sector.

Analysis of recent research and publications. Importance of effective innovation activity projects implementation and problems of innovative projects introduction gave rise to a considerable amount of Ukrainian and foreign researches. Irreproducible resources' saving problems, environmental issues do also make subject of numerous scientific publications. But the most acute need is that in a comprehensive study of the economic, innovative, environmental and applied aspects of this problem.

The research aim is to study the economic feasibility of using pellets as a source of energy as well as feasibility of offering at the domestic and foreign markets these promising competitive goods.

To achieve the formulated goal, the following tasks should be completed:

- Highlighting the importance of the national forest resources efficient use;

- Identifying the advantages of using wood pellets as a fuel;

- Specifying the main economic parameters of the pellets production project;

- Analyzing variances of possible economy when switching to pellets from various other fuels;

DOI 10.15276/opu.1.45.2015.31

(C) I.M. Yepifanova, S.V. Beznos, M.O. Morozova, 2015

ЕКОНОМІКА. УПРАВЛІННЯ 
- Assessing the economic effect along the pellet boiler standard lifespan.

Main Body. Forest as wood source takes a special and important place among all the natural resources that make up the colorful treasury of our country. It is a perfect, the most capable of reproducing natural system that gives more than 20000 species of valuable products for a large number of industries. The forest fund total area in Ukraine is 10,4 million hectares, so, forest cover in the country making 15,9\% [1]. Essential to note is that in developed European countries such as Sweden, Germany, United Kingdom, every precious tree is in a special account: the decision on cutting trees should be taken by a special commission and seconded by the local communities.

Although Ukraine has adopted a considerable number of laws on safeguarding and increasing the forest funds in the national scale, even individual private enterprises on the one hand can have a positive impact on the environment of our country, and on the other side get a positive economic effect from their business activities.

These measures include the introduction of wood-into-biofuel innovative recycling technology, namely, production and use of pellets as an energy feedstock. The pellets as grain-shaped fuel from wood and agriculture industry waste are well known at developed countries as efficient alternative to solid fuels, such as coal, wood briquettes etc [2...6].

The raw material for wood pellets production is provided by wood industry (sawdust and chips) and agricultural industry (sunflower seed husks, straw, etc) waste.

Physically pellets have the shape of pressed cylinders up to $25 \mathrm{~mm}$ diameter. The most widely used are pellets of $6 \ldots 10 \mathrm{~mm}$ diameter. Their physical and geometrical characteristics: diameter, length, density, moisture content, bulk density, are determined by the parameters of manufacturing enterprise equipment.

Top priority application of wood pellets is by way seconded with the annual $15 \%$-increase of wood and agricultural waste use in thermal energy industrial production as practiced in Europe, Scandinavian countries and North America.

Pellets as a fuel feedstock represent a real alternative to black coal and oil as their calorific characteristics are not inferior to these of coal, and the environmental safety index overpasses every competing energy source: the pellets combustion heat being close to the calorific value of coal, their combustion $\mathrm{CO}_{2}$ emission is $10 \ldots . .50$ times below the coal's analogic parameter and by the ash formation parameter, the pellets also have $15 . . .20$ times more ecology-friendly index. Experts in biofuels do rightly argue that pellets represent a full-fledged alternative to coal [3].

Pellets manufacturing is regulated with standard requirements proposed by the United States and introduced as the "Standard Regulations \& Standards for Pellets in the US: The PFI (pellet)". When closer considering such pellets classes as "Premium" and "Standard"; the "Premium" pellets grade according to the specification contains no more than $1 \%$ ash and the "Standard" ones' ash content never exceeds $3 \%$. The standard prescribes by the density, size of granules, humidity, dust content levels etc. Germany, too, has introduced its own standards for wood pellets (pellets): DIN 51731, establishing the pellets' expected length, humidity and dust content, and DIN+ standard. Austria uses the ONORM M 7135 standard, in the United Kingdom used is "The British Biogen Code of Practice for biofuel (pellets)", National standards practiced in Switzerland and Sweden are SN 166000 and SS 187120. In Ukraine, none national standards for wood pellets still never exist, so the manufacturers are mainly using the German ones: DIN 51731 and DIN+.

Notable are the pellets' advantages compared to ordinary wood waste:

- Higher calorific value in comparison to chips and lump wood waste, lower cost of production equipment for boiler plants up to $2 \mathrm{MW}$ capacity compared with non-processed waste wood incinerators;

- Pellets storage space can be at least $50 \%$-reduced comparing to the wood chips storehouse;

- The pellets can be stored in close vicinity to the living chambers (in the basement or utility rooms), since this material is biologically inactive, having underwent the thermal treatment;

- The granules are less susceptible to spontaneous ignition, as do not contain dust and spores, which can apart that induce an allergic response [3]. 
The European market of pellets in recent years is rapidly growing. Renewable energy sources in the European Union cover about $7 \%$ of total energy consumption, with a tendency to further growth. EU energy strategy envisages to reach the $20 \%$ level of total energy consumption coverage with such sources until 2020.

It should be noted that Ukraine has a significant stock of raw materials for biofuel production. Therefore, for our country, the introduction of an innovative project on pellets manufacturing and use is a promising and economically attractive one.

A special feature of the Ukrainian market of pellets today refers to its structure: the wood pellets production makes about $22 \%$ of total production. The hugest share (about $78 \%$ ) of pellets production represents pellets manufacturing of various crops processing waste.

Results. The biofuel (pellets) production requires arranging a pellet manufacturing line, which average cost according to price lists makes $274000 \mathrm{UAH}$ [2].

Table 1 shows the main economic parameters for the pellets production project.

Table 1

Pellets production project: main economic parameters

\begin{tabular}{l|c|c|c|c|c}
\hline \multicolumn{1}{c|}{ Parameters } & $1^{\text {st }}$ year & $2^{\text {nd }}$ year & $3^{\text {rd }}$ year & $4^{\text {th }}$ year & $5^{\text {th }}$ year \\
\hline $\begin{array}{l}\text { New products manufacturing and } \\
\text { commercialization, tons }\end{array}$ & 8008 & 8372 & 9100 & 10556 & 11648 \\
\hline $\begin{array}{l}\text { Product one unit manufacturing full } \\
\text { cost, UAH/tons }\end{array}$ & 791,5 & 844,81 & 929,29 & 1022,22 & 1124,44 \\
\hline $\begin{array}{l}\text { New product manufacturing expens- } \\
\text { es, UAH }\end{array}$ & 6338332 & 7072749 & 8456539 & 10790554 & 13097477 \\
\hline Selling price, UAH/tons & 1200 & 1320 & 1452 & 1597 & 1757 \\
\hline Enterprise's returns, UAH & 9609600 & 11051040 & 13213200 & 16857932 & 20465536 \\
\hline Enterprise's profit, UAH & 3271268 & 3978291 & 4756661 & 6067378 & 7368059 \\
\hline
\end{tabular}

Fig. 1 shows the cost and profit of the project. The growth in sales results in increase of the production costs, with concurrent increase in the enterprise's profits.

Thus, introduction of pellets production innovative technologies is attractive both from an environmental point of view and financial one as this product line has a payback period of about one year, and woodworking industries producing their own wood wastes are therefore exempt from the additional costs for the appropriate raw materials purchasing [2].

Below considered and analyzed are options for possible economy when switching to pellets instead of various fuels according to data shown in Fig. 2 [7].

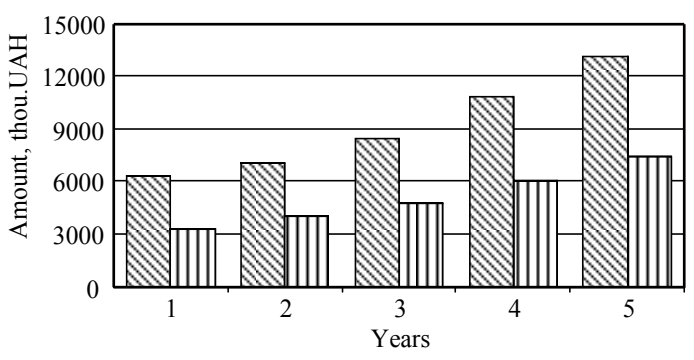

Fig. 1. Project expenses and profits ratio:

$\mathbb{Q}$ - new product manifacturing expenses; 四 - enterprise profit

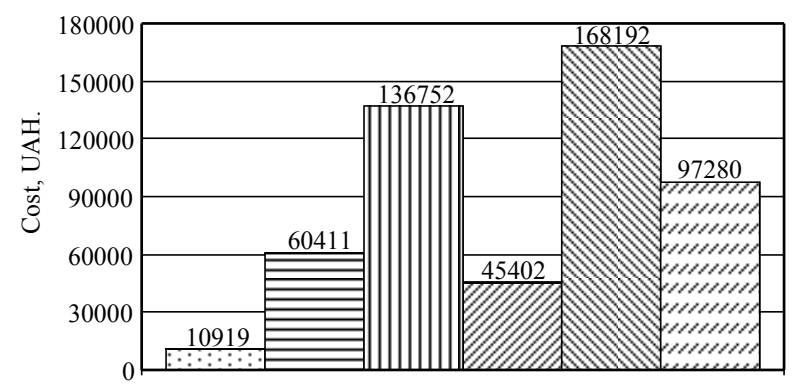

Fig. 2. Cost of heating $1000 \mathrm{~m}^{2}$ area during the heating season in Ukraine: $\quad$ - wood pellets; 目 — wood; 而_diesel fuel; $\square$ _ coal; $\mathbb{N}$ _ electric energy;

$$
\text { W- natural gas }
$$

In such a way, using the pellets, the economic effect during the heating season will be:

- pellets instead of diesel fuel 


$$
\frac{(136752-40919)}{40919} \times 100 \%=234 \% ;
$$

— pellets instead of electrical power $311 \%$;

- pellets instead of natural gas $138 \%$;

— pellets instead of ordinary wood $48 \%$;

- pellets instead of coal $11 \%$.

Therefore, whichever alternatives compared the economic effect is observed, and the most advantageous is the transition to pellets from electricity ( $311 \%$ economy), diesel fuel ( $234 \%$ economy) and natural gas (138\% economy). When transition from coal to pellets the economy percentage is relatively small $(11 \%)$, so it is reasonable to use technology of combined coal and pellets combustion in special boilers designed for various combustibles [5].

The cost of pellet boilers and burners purchase, depending on capacity and other technical and economic characteristics varies from 7 to 200 thousands UAH per one equipment unit, while the maximum lifespan of the boiler can be $15 . .20$ years [1...5].

For a rough calculation of net economy for heating during the normative pellet boiler lifetime we select a pellet boiler characterized with such parameters:

- pellet boiler value 30 thou. UAH;

- time factor is excluded from calculation;

— boiler's scheduled lifespan to the first TAR makes 7 years (average calculated value);

- extra costs for boiler operation over all scheduled lifespan make $15 \%$ of its value [7].

The economical effect resulting from various combustibles changing with pellets will amount to:

- electrical power case

$$
(168192-40919) \times 7-30000 \times 1,15=856411 \mathrm{UAH} ;
$$

- diesel fuel case $636331 \mathrm{UAH}$;

— natural gas case $360027 \mathrm{UAH}$;

— wood case $101944 \mathrm{UAH}$;

- coal case 3119 UAH.

Therefore the economy at transition from the traditional fuels (exception made to coal) to pellets varies from 856411 to 101944 UAH per $1000 \mathrm{~m}^{2}$ of heated area (Table 2).

Although the transition from coal to pellets has a positive environmental effect, but it is economically unfeasible. Therefore, reasonable is to conduct further investigation and feasibility study of such shift possibility identifying opportunities to use coal and pellets co-combustion technology.

Conclusions. Using pellets as fuel is promising, with respect to such consumption growth in Europe, and growing demand for pellets against the background of global process of energy sources differentiation, trends to increasing the renewable energy share in the structure of energy sources. Equally important is the role of pellets use for the national power system development and energy security of Ukraine in the presence of rich domestic potential for pellets production and consumption as well as export opportunities.

The implemented study leads to the following conclusion: wood pellets compared to wood, diesel fuel, electricity and natural gas are not only the most environmentally friendly, but also represent the cheapest fuel. Given the capital cost shifting from coal to pellets is uneconomical, but using a combined technology for burning coal and pellets (additional feasibility study imposed) can enhance the ecological processes of fuel burning with a positive economic effect.

According to the EIG Engineering analytical center in the nearest future in Ukraine will take start development and adoption of legal acts on biological

Economic effect from heating over a pellet boiler's scheduled lifespan (7 years) time factor excluding

\begin{tabular}{l|c}
\hline \multicolumn{1}{c|}{ Fuels } & $\begin{array}{c}\text { Economic effect from } \\
\text { transition to pellets, } \\
\text { UAH }\end{array}$ \\
\hline Electrical energy & 856411 \\
\hline Diesel fuel & 636331 \\
\hline Natural gas & 360027 \\
\hline Wood & 101944 \\
\hline Coal & -3119 \\
\hline
\end{tabular}


waste(biomass) mandatory energy utilization. This requirement will apply to all enterprises whose activities represent a source of biological waste (agriculture, forestry and food industries, etc.) [8]. These regulations adoption will dramatically increase the attractiveness of investing in bioenergy facilities, making this innovative technology extremely important for the Ukrainian market.

\section{Література}

1. Державний комітет лісового господарства України: офіційний веб-сайт [Електронний ресурс]. Режим доступу: http://dklg.kmu.gov.ua/ (Дата звернення: 09.08.2014).

2. ФОРА-ЗАХІД: Оборудование для производства биотоплива [Електронний ресурс]. — Режим доступу: http://fora-zakhid.com.ua (Дата звернення: 09.08.2014).

3. Тверде біопаливо України - інформаційний портал про тверде біопаливо та твердопаливні котли: виробники, обладнання, ціни, інформація [Електронний ресурс]. — Режим доступу: http://bio.ukrbio.com (Дата звернення: 09.08.2014).

4. Дунаевская, Н.И. Биоэнергетика в странах Юго-Восточной Азии. Состояние и перспективы / Н.И. Дунаевская, Я.И. Засядько, И.С. Шупик // Новини енергетики. — 2005. — № 2. - С. $44-52$.

5. Обзор технологий совместного сжигания биомассы и угля на электрических станциях зарубежных стран / Н.М. Жовмир, Г.Г. Гелетуха, Т.А. Железная, М.В. Сленкин // Пром. теплотехника. 2006. - Т. 28, № 2. - С. $75-85$.

6. Ткачев, А. Рынок пеллет Украины: комментарии аналитика отдела анализа рынков Аналитического департамента Pro-Consulting [Електронний ресурс] / А. Ткачев. - 2010. - Режим доступу: http://www.youtube.com/watch?v=mGSYA9uM8rs (Дата звернення: 09.08.2014).

7. Сравнительная характеристика оценочной стоимости топлива [Електронний ресурс] // ООО “Технический центр Радио системы”. - Режим доступу: http://gorelka.sumy.ua/dokum6.php (Дата звернення: 09.08.2014).

8. EIG Engineering - енергетична незалежність України [Електронний ресурс]. - Режим доступу: http://www.facebook.com/EIG.Engineering (Дата звернення: 09.08.2014).

\section{References}

1. State Forest Resources Agency of Ukraine. Retrieved from http://dklg.kmu.gov.ua/

2. Fora-Zakhid: Biofuel Production Equipment. Retrieved from http://fora-zakhid.com.ua/

3. Biofuel and Boilers in Ukraine. Retrieved from http://bio.ukrbio.com/ua/

4. Dunaevskaya, N.I., Zasyad'ko, Ya.I. and Shupik, I.S. (2005). Bioenergy in Southeast Asian countries. Status and prospects. Energy News, 2, 44-52.

5. Zhovmir, M., Geletukha, G., Zhelyezna, T. and Slenkin, M. (2006). Review of technologies for the cocombustion of biomass and coal on foreign power plants. Industrial Heat Engineering, 28(2), 75-85.

6. ProCapitalGroup. (2010, November 23). Pellet market in Ukraine [Video file]. Retrieved from $\mathrm{http} / / / \mathrm{www}$. youtube.com/watch? $=$ mGSYA9uM8rs

7. Automated Pellet Boilers (n.d.). Comparative characteristics of the estimated cost of fuel. Retrieved from http://gorelka.sumy.ua/dokum6.php

8. EIG Engineering - Ukraine's Energy Independence. Retrieved from http://www.facebook.com/EIG. Engineering

\section{АНОТАЦІЯ / АННОТАЦИЯ / ABSTRACT}

I.M. Спіфанова, С.В. Безнос, М.О. Морозова. Економічні та екологічні переваги впровадження інноваційного проекту на підприємствах деревообробної галузі. Орієнтування на інноваційний розвиток передбачає стратегічну спрямованість на випуск високотехнологічної і наукоємної продукції в пріоритетних галузях економіки країни. Впровадження інноваційних проектів, спрямованих на зменшення енергетичної складової в загальних витратах підприємства, є затребуваним і необхідним. Метою дослідження є доказ економічних і екологічних переваг використання на підприємствах деревообробної галузі країни паливних пелет як альтернативного біопалива. В роботі наведені основні показники проекту з виробництва пелет, вказується співвідношення витрат та прибутку, фіксується

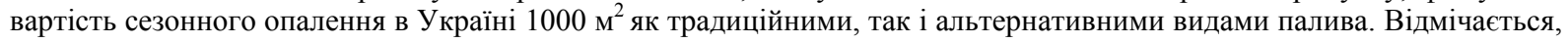
що економічно вигідним $\epsilon$ використання пелет - екологічного біопалива - в порівнянні 3 використанням електрики і газу. Наводиться економічний ефект при опаленні пелетного котла різними видами палива.

Ключові слова: альтернативні джерела енергії, інноваційний проект, пелети, економічний ефект. 
И.Н. Епифанова, С.В. Безнос, М.О. Морозова. Экономические и экологические преимущества внедрения инновационного проекта на предприятиях деревообрабатывающей отрасли. Ориентация на инновационное развитие предполагает стратегическую направленность на выпуск высокотехнологической и наукоемкой продукции в приоритетных отраслях экономики страны. Внедрение инновационных проектов, направленных на уменьшение энергетической составляющей в общих затратах предприятия, востребовано и необходимо. Целью научного исследования является доказательство экономических и экологических преимуществ использования на предприятиях деревообрабатывающей отрасли страны топливных пеллет как альтернативного биотоплива. В работе приведены основные экономические показатели проекта по производству пеллет, указывается соотношение затрат и прибыли,

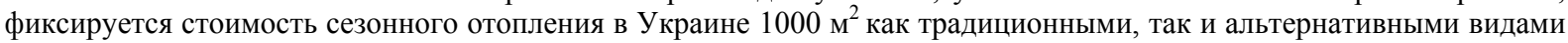
топлива. Отмечается, что наиболее экономически выгодным является использование пеллет - экологического биотоплива — по сравнению с использованием электричества и газа. Приводится экономический эффект при отоплении пеллетного котла различными видами топлива.

Ключевые слова: альтернативные источники энергии, инновационный проект, пеллеты, экономический эффект.

I.M. Yepifanova, S.V. Beznos, M.O. Morozova. Economic and ecological advantages of innovative project implementation at woodworking industry. Orientation to innovative development involves the strategic focus onto manufacturing high-tech products in the priority sectors of the economy. Implementation of innovative projects aimed at reducing the energy component in overall costs of enterprise is demanded and necessary. The aim of the research is to prove the economic and ecological benefits of using at domestic wood industry enterprises the wood pellets as an alternative biofuel. The main economic indicators of the project for the pellets production presented indicate the expenses-to-profits ratio; studied is the cost of season heating in Ukraine of $1000 \mathrm{~m}^{2}$ with both traditional and alternative fuels. Noted is that the use of pellets as ecological biofuel is more economical in comparison with electricity and gas. Exposed are the economic benefits of the pellet boiler heating by different fuels.

Keywords: alternative energy sources, innovative project, pellets, the economic effect.

Received September 22, 2014 